\title{
Determinants of Tourism and HIV/AIDS Incidence in West Java
}

\author{
Determinan Pariwisata dan Kejadian HIV/AIDS di Jawa Barat
}

\author{
Cecep Heriana*, Sohel Rana**, Rossi Suparman***, Dera Sukmanawati*
}

\begin{abstract}
*Institute of Health Sciences Kuningan, Kuningan, Indonesia, **Bridge of Community Development Foundation, Bangladesh, ***Linggarjati Public Hospital of Kuningan District, Kuningan, Indonesia
\end{abstract}

\begin{abstract}
Indonesia defined as tourist destination where the international and domestic tourists enjoy the tourist attractions. Prostitution existing in tourism place may increase the prevalence of HIVIAIDS. The incidence and the spread of AIDS in many areas in West Java become a problem for tourism industry. These issues become acute in locations where sexual attraction is used as a determinant of tourist portability. The aim of this study was to determine relation between tourism and the incidence of HIVIAIDS in West Java. Non-reactive research design was used to collect secondary data from the Statistics Indonesia (Badan Pusat Statistik) in 2016 from 26 districts/cities in West Java. This study was conducted in January - October 2016. This study applied univariate and bivariate analysis methods with Spearman's statistical test and multivariate analysis (multiple logistic). Bivariate analysis results showed that the number of star hotels, visit to accommodation, and average guest per day had $p$ value $<0.05$. Results of multivariate analysis showed that accommodation visits had $p$ value $<0.05$. In conclusion, tourism determinants associated with the incidence of HIVIAIDS are the number of star hotels, visits to hotel, and the average guest per day.
\end{abstract}

Keywords: HIVIAIDS, tourism, hotels

\begin{abstract}
Abstrak
Indonesia sebagai tujuan wisata yang dapat dinikmati oleh wisatawan domestik maupun internasional. Prostitusi yang ada di tempat wisata dapat meningkatkan prevalensi HIVIAIDS. Kejadian dan penyebaran AIDS di berbagai daerah di Jawa Barat menjadi masalah bagi industri pariwisata.Permasalahan ini menjadi sangat akut di lokasi dimana daya tarik seksual digunakan sebagai penentu portabilitas wisatawan. Tujuan penelitian ini untuk mengetahui hubungan determinan pariwisata dengan kejadian HIVIAIDS di Jawa Barat. Desain non reactive research menggunakan data sekunder dari Badan Pusat Statistik tahun 2016 dengan sampel sebanyak 26 kabupaten/kota di Jawa Barat yang dilaksanakan pada bulan Januari-Oktober 2016. Penelitian ini menggunakan metode analisis univariat dan bivariat dengan uji statistik Spearman dan analisis multivariat (regresi linear). Hasil analisis bivariat menunjukkan bahwa jumlah hotel berbintang, kunjungan ke akomodasi, dan rata-rata tamu per hari memiliki nilai $p<0.05$. Hasil analisis multivariat menunjukkan bahwa kunjungan ke hotel memiliki nilai $p<0.05$. Sebagai kesimpulan, determinan pariwisata yang berhubungan dengan kejadian HIVIAIDS yaitu jumlah hotel berbintang, kunjungan ke hotel dan rata-rata tamu per hari.
\end{abstract}

Kata kunci: HIVIAIDS, pariwisata, hotel

How to Cite: Heriana C, Rana S, Suparman R, Sukmanawati D. Determinants of tourism and HIV/ AIDS incidence in West Java. Kesmas: National Public Health Journal. 2018; 12 (4): 153-158. (doi:10.21109/ kesmas.v12i4.1293)
Correspondence: Cecep Heriana, Institute of Health Sciences Kuningan, Lingkar Kadugede Street No. 2 Kuningan, Phone: +62232875847, E-mail: cecepheriana@gmail.com

Received: December $3^{\text {rd }} 2016$

Revised: January 24th 2018

Accepted: February $7^{\text {th }} 2018$ 


\section{Introduction}

Human Immunodeficiency Virus (HIV) and Acquired Immunodeficiency Syndrome (AIDS) diseases are still health problems in many countries in the world with the high rates of transmission, morbidity, and mortality. Data of HIV cases globally in 2011 indicate that 34 million people are living with HIV with details of 30.7 million of those people are adults, 16.7 million of those infected are women, and 3.3 million children are under 15 years of age. There are 2.5 million new HIV-infected people consisting of 2.2 million adults and 330,000 children under the age of 15 years. Meanwhile, the number of deaths due to AIDS is 1.8 million people consisting of 1.5 million adults and 230,000 children under the age of 15 years. ${ }^{1}$

HIV is retrovirus that infects cells of human immune system, especially CD4 positive T-cells and macrophages of the major components of the cell immune system, and destroys or disrupts its function. This viral infection results in a persistent decline in the immune system, which will lead to immune deficiency and this is the AIDS. Thus HIV infection has been determined as the cause of AIDS with indicators of HIV level in the body and the incidence of certain infections. This suggests that HIV infection has developed into AIDS. ${ }^{2}$

Conditions that support the increasing prevalence of HIV in a region are the sex industry in tourism activity and the high mobility of tourists, who take travels and visits to tourist destinations. ${ }^{3-5}$ In current situation, human trafficking, sexually transmitted infections, pressure from local communities, and threats to image changes in tourist destinations cannot be avoided. ${ }^{6}$ The number of tourists visiting the tourist attractions in Indonesia continues to increase from year to year around $10 \%$ annually where Bali contributes the highest among several provinces. Indonesia as a tourist destination, which has various forms of tourist destinations that can enjoy both domestic and international tourists, has a risk as an area that may increase the prevalence of HIV and AIDS. This is evident from HIV data that shows the increasing trend annually. ${ }^{4}$ Based on cumulative data of AIDS cases in Indonesia, as many as 22,726 cases spread across 32 provinces. The highest case is dominated by productive ages, such as the age of 20-29 years $(47.8 \%)$, followed by the age group of $30-39$ years $(30.9 \%)$, and the age group of $40-49$ years $(9.1 \%)$. Of the total, as many as 4,250 cases $(18.7 \%)$ died. ${ }^{8}$

West Java Province that has many destinations attracting tourists to visit also has a risk of the increasing HIV and AIDS cases. Study by Heriana, ${ }^{9}$ finds a relation between classification of area (tourism/non-tourism) around district/city in West Java and the prevalence of HIV and AIDS. Based on national data, West Java is included into eight provinces with the highest number of the case in Indonesia. Data of HIV/AIDS cases in West Java accumulatively since 1987 up to March 2013 present 7,621 HIV cases and 4,131 AIDS cases. Based on this data, the trend of increasing HIV transmission has occurred in 2008 as much as $67 \%$ of new HIV and AIDS cases dominated by injecting drug use. While in 2012, new cases of HIV and AIDS are dominated by heterosexual factor amounted to $64 \%$ of the total cases. HIV and AIDS in West Java spread across all districts/cities with the highest data of cases in Bandung City, Bekasi City and Sukabumi City, while the area with the lowest case of HIV/AIDS is Banjar City until the end of 2012 with 11 cases recorded. 10

Factors affecting on the increasing prevalence of HIV and AIDS are tourism industry and tourists' visits. Tourist is a person who visits in an area outside his/her residence for at least 24 hours driven by a variety of purposes, such as vacation, recreation, sports, business, visiting friends and family, missions, attending meetings, conferences, visits for health, study, and religion reasons. ${ }^{7}$ HIV prevalence is increasing rapidly in areas known as tourist destinations including sex industry. ${ }^{5}$ This increase in prevalence is affected by visits to tourist attractions enjoyed by tourists, visits to hotels as temporary residence of tourists, and many star hotels including tourists' per-day visit. ${ }^{11}$

By the increase in visit to tourist attractions and accommodation (hotel) by tourists in the last 30 years, it is almost impossible that the spread of infectious disease transmission can be prevented. ${ }^{12}$ The risk of HIV infection will be increased if condoms are unavailable in star hotels and unqualified. Regarding the actual use of condoms, a study found only $34 \%$ of sex tourists from Switzerland consistently use condoms while abroad. A total of $28 \%$ of men in the Melbourne clinic, Australia, reported the consistent use of condom during sexual intercourse while traveling in Asia, and sexually transmitted diseases were identified in $73 \%$ of men examined. ${ }^{5}$ The incidence and the spread of AIDS in various regions become a problem for district/city areas with regional income mainly from the tourism industry. These problems become acute in locations where sexual attraction is used as a determinant of tourist portability. The tourism industry and tourism policy makers have just began to see the problem of the impact of tourism associated with the incidence of AIDS, which has so far not been explored or certainly defined yet. The complex problems emerging from between tourism and AIDS deserve a systematic indepth study. The aim of study was to determine the relation between tourism and the incidence of HIV/AIDS in West Java.

\section{Method}

This study used non-reactive research design by using 
secondary data, which is the results of Statistics Indonesia (Badan Pusat Statistik) survey in 2017 conducted in West Java Province. Data were collected in the form of secondary data obtained from several related institutions including data of HIV and AIDS cases, the number of hotels, the number of visits to tourist attractions, the total of accommodation visits and the average number of visitors per day in districts/cities over West Java Province that were obtained from the records by Central Bureau of Statistics of West Java Province. Data collected were then processed by using SPPS and analyzed. Data analysis was conducted gradually, namely univariate, bivariate and multivariate analysis. Univariate analysis included frequency distribution of the number of hotels, visits to tourist attractions, accommodation visits and average visitors per day in districts/cities over West Java Province. Bivariate analysis was conducted to determine relation including independent and dependent variables. Statistical test in this analysis used Spearman. This analysis would obtain independent variables significantly related or not related to dependent variable. Multivariate analysis was conducted with linear regression test consisting of two stages. The first stage was interaction test in aim to exclude variables with $\mathrm{p}$ value $>$ 0.05 , then the selection of logistic regression model candidates was conducted by including all independent variables that met the requirements into the model. Insignificant variables were excluded gradually, starting from variables with the highest $p$ value, so those variables would be determined as fit model by considering the best model of two assessments, namely ratio Log likelihood ( $\mathrm{p}$ value $<0.05) .13$

The location of study was in West Java Province. This study was conducted within 9 months, from January 2015 to October 2015. Population of study was HIV and AIDS incidence in every district/city in West Java Province. Samples in this study were the complete data of HIV and AIDS incidence in district/city in West Java Province by taking non-probability sampling using Exhauting Sampling. Variables in this study consisted of independent and dependent variables. Independent variable consisted of the number of hotels, visits to tourist attractions, accommodation visits, and average visitors per day in district/city over West Java Province.
Dependent variable was the incidence of HIV and AIDS in West Java Province.

\section{Results}

Based on univariate analysis results, the number of visits to tourist attractions, accommodations, star hotels and average visitors per day can be seen. The average visits to tourist attractions in West Java was $1,064,570$ visitors with median 510,471 and deviation standards $1,349,947$. The average accommodation visits in West Java was 409,004 times per year with median 116,996.50 and deviation standard 827,377.752. The average number of star hotels in West Java was 8.85 hotels with median 3.50 and deviation standard 19.174. The average visitors per day in hotels in West Java was 504.08 visitors every year with median 319 and deviation standard 659.281 (Table 1).

Bivariate analysis with correlation test obtained that accommodation visits, the number of hotels, and average visitors per day had strong and positive relation with $\mathrm{r}=$ 0.069; 0.499; 0.552; and 0.447 respectively. This means that the more number of visits to tourist attractions, the more HIV incidence increasing. The more accommodation visits, the more HIV incidence increasing. The more number of hotels, the more HIV incidence increasing. The more average number of visitors per day, the more HIV incidence increasing. Meanwhile, visits to tourist attractions did not have correlation with HIV incidence (Table 2).

Based on results of bivariate analysis with Spearman rank test, there were three variables that met the requirement to apply multivariate analysis. The requirement to involve independent variables in multivariable analysis was $p$ value $=<0.25$, then variables which met the requirement were the number of hotels, accommodation visits, and average visitors per day (Table 2).

Furthermore, to determine the dominant variable influential to HIV/AIDS incidence in West Java Province, multivariate analysis with linear regression test was then conducted. Linear regression test was done gradually by backward method until the simplest final model obtained, in which all variables had $\mathrm{p}-$ Wald $<0.05$, and the results of analysis were as presented in Table 3 .

Multivariate analysis was applied to determine the

Table 1. Results of Univariate Analysis

\begin{tabular}{lrrrr}
\hline Variable & \multicolumn{1}{c}{ Mean } & Median & \multicolumn{1}{c}{ SD } & \multicolumn{1}{c}{ Min - Max } \\
\hline Visits to tourist attractions & $1,064,570$ & 510,471 & $1,349,947$ & $0-5,645,569$ \\
Accommodation visits & 409.004 & $116,996.50$ & $827,377.75$ & $2,400-3513705$ \\
Star hotels & 8.85 & 3.50 & 19.17 & $0-99$ \\
Average visitors per day & 504.08 & 319 & 659.28 & $24-3.160$ \\
\hline Notes: & & & & \\
SD $=$ Standard Deviation & & & &
\end{tabular}


dominant factor of HIV incidence in West Java. The dominant factor was determined by examining standardized coefficient of each independent variable. In Table 3, model selection was conducted on all independent variables that met the requirements included into the model. Insignificant variables were excluded gradually starting from variable with the highest $p$ value. Based on multivariate analysis applying the requirement $p<0.25$, variable the average visitors per day ( $p$ value $=0.538$ ) was excluded at the first stage of interaction test. In the second stage of interaction process, variable the number of hotels was excluded ( $p$ value $=0.432$ ). The final stage of linear regression results obtained variable the accommodation visits ( $p$ value $=0.000, r=0.704$ ). By the independent variable with the highest value of standardized coefficient from the most fit and qualified model, accommodation visit was determined as the dominant factor of the increasing HIV incidence in West Java with standardized coefficient. Multivariate analysis obtained three variables that became model candidates ( $\mathrm{p}$ value $<0.25$ ), namely the number of hotels, accommodation visits and the average visitors per day. After the interaction test was conducted, variable determined as the fit model was accommodation visits with the equation as follows Equation 1.

Equation 1.

$$
\mathrm{Y}=86.786+0.000 \mathrm{X}_{1} \text { (accommodation visits) }
$$

Table 2. Results of Bivariate Analysis

\begin{tabular}{lll}
\hline \multirow{2}{*}{ Variables } & \multicolumn{2}{c}{ HIV Incidence } \\
\cline { 2 - 3 } & $\mathbf{r}$ & $\mathbf{p}$ Value \\
\hline Visits to tourist attractions & 0.069 & 0.737 \\
Accommodation visits & -0.499 & 0.009 \\
Number of star hotels & -0.552 & 0.003 \\
Average visitors per day & -0.447 & 0.022 \\
\hline
\end{tabular}

\section{Discussion}

Tourism areas in West Java are more risky to get exposed to HIV infection than non-tourism areas. ${ }^{9}$ The prevalence of HIV incidence in West Java continuously increases, up to the end of 2014, as many as 5,178 HIV cases spread across 26 districts/cities in West Java. District/city with the highest number of HIV and AIDS cases is Bandung City with 653 and 1750 cases, and the lowest is Purwakarta District with no case found. The highest prevalence occurs in 7 districts/cities and the lowest in 19 district/cities in West Java. Most of districts and cities in West Java belong to regions that have tourist destinations, both natural and artificial tourisms, and available accommodations for tourists. Moreover, every district/city in West Java has supporting facilities, such as hotels as the transit place for tourists to visit any tourist destinations.

Related to accommodation problem, hotel is one of accommodation types which mostly taken in the world as proven by the highest number of rooms of all accommodation types are those provided by hotels. Definition of hotel itself is one type of accommodation in which the building is used partly or entirely to provide lodging service, food and beverages as well as other supporting public services, and managed commercially. ${ }^{14}$ Accommodation visits based on results of this study had a significant relation to the prevalence of HIV incidence in West Java Province. This is because tourists take trips to attracting places or tourist attractions and will enjoy the atmosphere of region in aim of refreshing, seeking tranquility and comfort and getting pleasure and happiness by being in the tourist attraction, by staying temporarily (stay) at hotels to enjoy the beauty of the tour. So that, there is a tendency to perform sexual transactions and sexual intercourse that can be done at the hotels. In addition, hotel has the attraction of entertainment venue that have commercial sex workers. ${ }^{2}$

Table 3. Results of Multivariate Analysis

\begin{tabular}{|c|c|c|c|c|c|}
\hline \multirow{2}{*}{ Model } & \multirow{2}{*}{ Variable } & \multicolumn{2}{|c|}{ Unstandardized Coefficients } & \multirow{2}{*}{$\frac{\text { Standardized Coefficients }}{\beta}$} & \multirow{2}{*}{ p Value } \\
\hline & & $\beta$ & SE & & \\
\hline \multirow[t]{4}{*}{ Model 1} & Accommodation visits & 0.00 & 0.00 & 1.93 & 0.067 \\
\hline & The number of hotels & 3.46 & 3.50 & 0.41 & 0.033 \\
\hline & Average visitors & -0.05 & 0.09 & -0.22 & 0.538 \\
\hline & Constants & 97.42 & 32.77 & & 0.007 \\
\hline \multirow[t]{3}{*}{ Model 2} & Accommodation visits & 0.00 & 0.00 & 0.52 & 0.065 \\
\hline & The number of hotels & 1.82 & 2.27 & 0.22 & 0.432 \\
\hline & Constants & 85.20 & 25.96 & & 0.003 \\
\hline \multirow[t]{2}{*}{ Model 3} & Accommodation visits & 0.00 & 0.00 & 0.70 & 0.000 \\
\hline & Constants & 86.79 & 25.69 & & 0.002 \\
\hline
\end{tabular}


Tourism area including tourist accommodation is the epicenters of demographic and social changes in relation to HIV risk, such as sexual transaction, increase in use of alcohol and other addictive substances, and internal migration. ${ }^{15}$ Tourists who have taken tours already involve in romantic and sexual meeting from many types of tourist activities. Sometimes, sexual transaction or prospects of sexual intercourse during tour in the destinations and tourist accommodation would be the main reasons to decide in selecting tourist destinations. ${ }^{6}$ Sexual meeting in tourist accommodation on holiday potentially becomes the major cause of morbidity, and the risk is an increase in sexual disease cases including HIV and most likely to occur among young people and tourists. ${ }^{16}$ Results of study by Rice et al., 17 in UK shows that the great number of adults born in UK obtain HIV infection in general HIV-epidemic countries, and in public holiday destinations including tourist accommodation. The particular concern is the high proportion of men infected because of sexual intercourse with commercial sex workers.

Hotel as tourist accommodation has grade called as star hotel. The star hotel is a business that uses a building or partial building provided specifically, and everyone can stay, eat and get services and other facilities by making payment and have met the requirements. Classification of star hotels is based on standard requirements and operational technique assessment. Results of this study show a significant relation between availability of star hotels in a district/city region and HIV prevalence. Ethnographic study in one of hotels in San Fransisco finds that based on cultural concept, there are several themes revealed including the meaning of hotel as supporting community for tourists. ${ }^{18}$ Tourism area is not only the center of tourist visits, but also as continuously growing place of densely populated areas. Because of development of the region that is tourist destination area, this will affect on the great development of hotel, so star hotels are slowly established as one of tourist attractions. Moreover, in line with the development of the tourism area, entertainment facilities start to arise. These arising entertainment facilities are stalls, café around storefront, massage place, karaoke place and night club. These entertainment facilities become factor for the possibility of sex business transactions or prostitution localization. Tourists visiting to tourist destinations mostly choose hotels with many stars than standard class hotel because of many reasons, such as the large room to stay, comfort, hygiene and any other facilities offered by star hotels. The more number of star rate in a hotel, the more facilities provided. ${ }^{14}$ This includes facilities that let sex business transaction, so that sex transactions will occur between customers and the sex workers in star hotels, which affects on the increasing disease prevalence of HIV infec- tion.

By the number of star attached to hotel as the accommodation place, therefore, this will increase visit of tourists from many regions going to tourist area, then increase the average number of visitors per day coming to a tourist region. ${ }^{19}$ Based on data obtained from results of study, the average visitors per day coming to a tourist attraction had a significant relation to the prevalence of HIV case in a region. Visitors coming to a tourist attraction generally have a purpose to stay temporarily to enjoy tourism potential in an area or to attend a work/business meeting. The longer the day spent to visit tourist attractions, the greater possibility of tourists to enjoy existing facilities in the area, including the possibility for tourists trying sexual business transactions. According to study by Trong T.H.A.O conducted in Northern Tanzania, the risk factors of the increasing HIV case prevalence occur on women who have more than one sexual partner. ${ }^{20}$ This is in line with study by Ramadhani et al., 21 stating that characteristics of tourism area relates to HIV incidence in South Sulawesi Province with p value 0.019. This is because of the high number of tourists who are mobile in and out of the tourist area and enjoy the beauty of the tour by staying temporarily in the hotel around tourist attractions, so the number of tourist visits in tourist area is the cause of spread of HIV/AIDS disease due to entertainment vanues that have commercial sex workers. 22

Tourism sector significantly contributes to the economy of a country including local government. ${ }^{23}$ Nevertheless, there is a phenomenon emerged from the tourism activity towards environment, socioculture and economy of community living around the tourist destination. As a result of this phenomenon, various negative activities arise, one of which is prostitution activity. Prostitution from any perspectives is an illegal activity in Indonesia, in terms of law, social, and religion. ${ }^{9}$ Prostitution resulted from tourism activities is evolving covertly and difficult to eradicate, even though it has already been a public secret. 24

The development of prostitution activity is a logical consequence of the development of tourism activity. Diseases because of sexual intercourse nowadays also become the effect of the development of tourism which contains prostitution activity. ${ }^{4}$ This is due to misleading assumption that sexual actvities not only generally aim to create generation, but also to be as procreation (getting enjoyment and pleasure) as well as entertainment to fulfill biological needs of human. ${ }^{25}$ For the countermeasures, effective and efficient policy is needed, however, the perspective of the local government concerning HIV/AID will be very decisive towards the policy. ${ }^{26}$

The prostitution activity that is rampant around tourist destinations cause tourism sector associated with 
the spread of HIV/AIDS virus. The number of tourist visits in tourism areas can also be considered as the cause of the spread of HIV/AIDS disease. This is due to entertainment venues that have commercial sex workers. ${ }^{27}$ In addition, the high number of tourists in contact with the local people accelerates the spread of AIDS disease. Thus the number of HIV/AIDS cases will increase steadily along with the development of tourism industry if there is no optimal prevention and control. Provinces advanced in tourism industry have a high number of HIV/AIDS patients.

\section{Conclusion}

In conclusion, there is a relation found between tourism determinants, namely accommodation, the number of star hotels, and the average visitors per day with HIV/AIDS incidence in West Java. Meanwhile, visits to tourist attractions and HIV/AIDS in West Java do not have relation. Results of multiple logistic regression test shows that the most dominant variable is accommodation visits correlated with HIV/AIDS incidence in West Java. The recommendation for the Government of West Java Province is that the attempt to overcome HIV/AIDS should consider characteristics of tourism through the improvement of health promotion in tourist attractions. Tourism office and local health office there need to make cooperation in prevention of disease, and health promotion in place of tourism.

\section{Acknowledgment}

This study is funded by Research Grants for Beginner Lecturer Year 2015 (Hibah Penelitian Dosen Pemula Tahun 2015) from Directorate General of Higher Education, Ministry of Research, Technology, and Higher Education.

\section{References}

1. World Health Organization. Global summary of the HIV/AIDS epidemic. 2013.

2. Hoyle B. AIDS/HIV. United States of America: Thomson Gale; 2006.

3. Rokhmah D. Implikasi mobilitas penduduk dan gaya hidup seksual terhadap penularan HIV/AIDS. Kemas: Jurnal Kesehatan Masyarakat. 2013;9(2):183-90.

4. Clift S, Page S. Health and the international tourist (routledge revivals). New York: Routledge; 2015.

5. Herold ES, van Kerkwijk C. AIDS and sex tourism. AIDS Society. 1992;4(1):1-8.

6. Yeoman I, Mars M. Robots, men and sex tourism. Futures. 2012; 44(4): 365-71.

7. Hakim A, Khan A. Problematika penyakit pribumi bagi para wisatawan asing di Kota Manado. Intisari Sains Medis. 2011; 1(1): 24-8.

8. Kementerian Kesehatan Republik Indonesia. Laporan tahunan
HIV/AIDS tahun 2014. Jakarta: Kementerian Kesehatan Republik Indonesia; 2014.

9. Heriana C, Nurjannah SN. Distribusi spasial dan determinan kejadian HIV/AIDS di Jawa Barat. Jurnal Online Sekolah Tinggi Ilmu Kesehatan Kuningan. 2015; 4 (2): 1-10.

10. Kementerian Kesehatan Republik Indonesia. Statistik kasus HIV/AIDS di Indonesia, Laporan Trinitlan IV tahun 2010. Jakarta: Kementerian Kesehatan Republik Indonesia; 2010.

11. Cossens J, Gin S. Tourism and AIDS: the perceived risk of HIV infection on destination choice. Journal of Travel and Tourism Marketing. 1995; 3(4): 1-20.

12. Hawkes SJ, Hart GJ. Travel, migration and HIV. AIDS Care. 1993; 5(2): 207-14.

13. Sugiono. Statistik kesehatan. Bandung: Alfa Beta; 2011.

14. Sulistiono AB, Shuhada S. Pengaruh kualitas pelayanan, fasilitas dan lokasi terhadap keputusan menginap (Studi pada tamu hotel srondol indah Semarang) [skripsi]. Semarang: Universitas Diponegoro; 2010.

15. Mark B. Padilla, Guilamo-Ramos V, Bouris A, Reyes AM. HIV/AIDS and tourism in the Caribbean: an ecological systems perspective. American Journal of Public Health. 2010; 100(1): 70-7.

16. Rogstad KE. Sex, sun, sea and STIS: sexually transmitted infection acquired on holiday. Biomedic Journal. 2004; 329 (7459): 214-7.

17. Rice B, Gilbart VL, Lawrence J, Smith R, Kall M, Delpech V. Safe travels? HIV transmission among Britons travelling abroad. HIV Medicine Journal. 2012; 13 (5): 255-317.

18. Carr G. Ethnography of an HIV hotel. Journal of the Association of Nurses in AIDS Care. 1996; 7(2): 35-42.

19. Evita R, Sirtha IN, Sunarta IN. Dampak perkembangan pembangunan sarana akomodasi wisata terhadap pariwisata berkelanjutan di bali. Jurnal Ilmiah Pariwisata. 2012; 2(1): 109-222.

20. Oktavia F, Banun S, Setyorogo S. Faktor-faktor yang berhubungan dengan perilaku seksual pranikah pada mahasiswa semester V STIKes X Jakarta Timur 2012. Jurnal Ilmu Kesehatan. 2013; 5(1): 12-9.

21. Ramadhani HH, Aminudin R, Bahar B. Pemetaan dan faktor yang berhubungan dengan kejadian HIV dan AIDS di Provinsi Sulawesi Selatan tahun 2013. Masyarakat Epidemiologi Indonesia. 2013; 2(2): 98-102.

22. Mishra S, Boily MC, Schwartz S, Beyrer C, Blanchard JF, Moses S, et al. Data and methods to characterize the role of sex work and to inform sex work programs in generalized HIV epidemics: evidence to challenge assumptions. Annals of Epidemiology. 2016; 26 (8); 557-69.

23. Adi PH. Hubungan antara pertumbuhan ekonomi daerah, belanja pembangunan dan pendapatan asli daerah. Simposium Nasional Akuntansi Padang. 2006.

24. Pratama T. Dampak sosial dan ekonomi pasca penutupan prostitusi liar (studi kasus di kawasan wisata Gunung Kemukus Desa Pendem Kecamatan Sumberlawang Kabupaten Sragen) [disertasi]. Solo: Universitas Sebelas Maret; 2017.

25. Rasmaliah D. Epidemiologi HIV/AIDS dan upaya penanggulangannya [skripsi]. Medan: Universitas Sumatera Utara; 2001.

26. Lestari TRP. Kebijakan pengendalian HIV/AIDS di Denpasar. Kesmas: National Public Health Journal. 2013; 8 (1): 45-8. 